\title{
Safety Issues Related to the Adoption of the Digital Dialogue in Teaching
}

\author{
Momčilo RANĐELOVIĆ ${ }^{1}$, Miloš PAPIĆ ${ }^{2}$, Marija BLAGOJEVIĆ \\ ${ }^{1}$ Electro Technical High School "Nikola Tesla" \\ Aleksandar Medvedev 18, 18000 Niš, Serbia \\ moca@etstesla.ni.ac.rs \\ ${ }^{2}$ University of Kraguevac, Faculty of Technical Sciences Čačak \\ Svetog Save 65, 32000 Čačak, Serbia \\ milos.papic@ftn.kg.ac.rs \\ marija.blagojevic@ftn.kg.ac.rs
}

\begin{abstract}
This paper describes the concept of the digital dialogue in teaching as an efficient way to use the educational potential of smart phones and other Internet of Things' devices. At the same time, the paper investigates to what extent the non-ionizing radiation caused by the use of these devices is safe for teachers and students alike. Such research is necessary due to the increasing frequency of wireless networks usage. By direct measurements at one vocational high school in Serbia, we have determined strengths of magnetic and electric fields at various points in the classroom during the implementation of the digital dialogue. The measurement results have been compared to national and international standards for safety levels of radiation in electromagnetic fields. It has been determined that the level of radiation according to the standards is far below the critical. Nevertheless, this kind of testing should be constantly renewed and even extended, so that insights into the living and working environment of sensitive facilities such as schools may be provided.
\end{abstract}

Keywords: digital dialogue, $\mathrm{Wi}-\mathrm{Fi}$, routers, smartphones, nonionizing radiation measurements, safety levels.

\section{Introduction}

Traditional teaching in secondary schools is pragmatic-oriented and supports formal and logical ways of empirical generalization, which means that the opinion of students relies on external characteristics which can be noticed by direct observation, and it has a sporadic and insufficient influence on the training of students to think independently [15]. As a way to overcome the shortcomings of traditional teaching in secondary schools, the theory of didactics recommends increasing the interaction of teaching subjects during the presentation [25].

In order to achieve a better interaction, teachers need a didactic tool that would enable all of the students to simultaneously take part in a dialogue with them. Ranđelović et al. [18] state that "such a dialogue should enable a teacher to have a precise insight in the number of students that actively participate in the lecture, to get information during the class whether and how a teaching unit is accepted by the students, and even to evaluate the activity of each student at the same time". With that aim, the use of the Internet of Things (IoT) in education [24], for instance smart phones, in accordance with the BYOD (Bring Your Own Device) program [9], together with the software applications for the exchange of information between a teacher and students, can create a new, higher level of multimedia interactive teaching called digital dialogueThe digital dialogue in teaching, based on the use of smart mobile devices and cloud technology, is a combination of gamification, digital clickers, mobile learning and multimedia teaching. These types of digital dialogue records are significant in that they capture "live collaborative thinking" [20]. Conversely, Bester \& Brand in [4] state that no technology is able to replace the teacher in the classroom. However technology can be successfully integrated into lessons which could maximise the learning experience since technology has become an integral part of the life world of today's learners.

A review of research literature on digital dialogues may show that the issue is still under development. In relation to the research presented in [20], which promotes dialoguerich networked learning, proposed approach 
integrates the digital dialogue into hybrid learning system and includes a number of activities involving interaction between teacher and students. Ravenscroft [21] showed that Learning through play (game based learning) can also be successfully realized via digital dialogue. Creating a digital dialogue "connects social and conceptual dimensions of learning process", as Ravenscroft and Mcalister stated in [19].

In order to create digital dialogue in teaching, it is also necessary that safety requirements should be met besides the pedagogical, technical and technological parameters. Namely, all electronic didactic tools used in teaching are the additional sources of electromagnetic radiation [13]. Dawoud [6] states that the concern about human health effects is "more for the hand-held mobile phones" rather than the base stations. This concern is because the mobile phone antennas deliver much of their RF energy to very small volumes of the user's body. Numerous studies have dealt with the issue of impact of the use of cell phones on human health $[1,7,11,12,16$, $17,23]$.

Since wireless routers and mobile telephones (smartphones) have started to become widely used it is necessary that technical requirements for "the implementation of the concept of digital dialogue in teaching" as shown in [18] should also be met. The aims of this paper are the following: (1) to measure and analyse the electromagnetic fields of the wireless routers TL-WR 340G [10] and AT-WA1104G [1], which are necessary for the digital dialogue in a classroom; (2) to measure the electric and magnetic fields of students' smartphones which are used in the school environment during the digital dialogue; (3) to compare the obtained results with domestic and international reference levels of radiation.

\section{The Concept of the Digital Dialogue in Teaching}

The concept of digital dialogue complements the system of blended learning, because it enables to overcome the limitations of elearning and direct teaching by being placed between them (Figure 1).

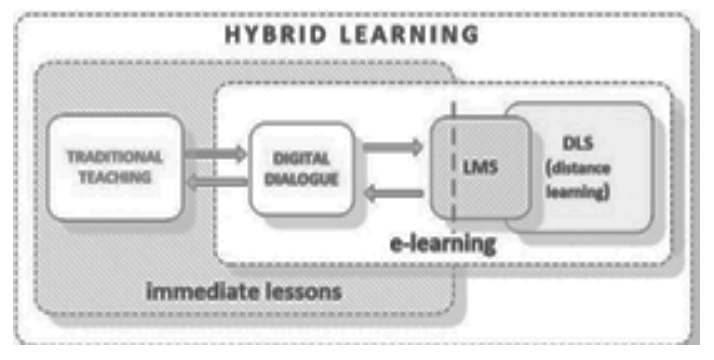

Figure 1. The position of the digital dialogue in the hybrid learning system (Source: [18])

Adopting the concept of digital dialogue as an asymmetric communication process, integrated into the hybrid learning system, includes a number of activities involving a constant interaction between teacher and students, such as: synchronized testing, quiz, poll, electronic book of impressions, connection to LMS, group work, system for recording attendance, textvisual correspondence and voting.

By introducing the practice of students' active participation in classes using their own mobile devices (BYOD program), the digital dialogue gets the characteristics of a modern, inexpensive and efficient didactic means.

\section{Implementation of the Digital Dialogue in Teaching by Using Byod Program}

The program of using personal devices for business purposes BYOD (Bring Your Own Device) has originated in companies, but since 2012, owing to a rapid increase of the mobile device performances, the program has been widely applied in educational institutions as well [20]. In research conducted by Thorsteinsson and Niculescu [26] smartphones were used by students instead of conventional notebooks to support their ideation. Afterwards, Thorsteinsson et al. explored the usefulness of the mobile application NeedIT in fostering ideation and idea generation in a school context [27].

The advantages of application of BYOD program are primarily the following:

- greater involvement of students in classes - students enjoy using their own devices, so they are always willing to use them in classroom for learning and teaching purposes; 
- students get more control over their own learning (they can ask questions, explore and directly respond instead of just listening to lectures);

- more effective communication between students and a teacher leads to better cooperation, which is a key for more efficient work on solving problems, running projects, etc.;

- savings - although BYOD is an innovation in teaching, it saves money, because students use their own devices, and educational institutions' existing infrastructure;

- the possibility to personalize teaching different learning styles can be met, allowing the students to study the material at their own pace;

- a new way of learning - by encouraging students to use their own mobile devices to master the curriculum they are directed towards project and research learning and practically, by learning by doing, they manage their own education.

On the other hand, in order to realize BYOD program, it is necessary to meet the following requirements:

- technical requirements and administrative compliance which must include: checking the identity of a subject in the educational process, the full protection of data transmission, the protection from unauthorized access and compatibility of hardware and software components.

- safety requirements - since various electronic devices are used during teaching it is essential that their work does not endanger the health of students and teachers, that is, that it complies with the prescribed health and environmental standards;

\section{Technical requirements for the digital dialogue in teaching}

Implementation of digital dialogue in teaching requires electronic components standard for CRS (Classroom Response System) environment, including the information system (IS) which has its own appropriate hardware, system and dedicated application software, database, communicational system and methods of data processing. The communicational system for implementation of digital dialogue should connect all the subjects of the teaching process, which is more and more often realized via the Internet and a wireless network [8].

Ranđelović et al. [18] state that "system that connects students' devices with the teacher's computer can be based on different technologies: infrared (IR), radio-frequency (RF), SMS, Wi-Fi, and LAN. It is necessary to ensure that a local server can simultaneously receive in real time the large number of responses from students' mobile devices PRS (Personal Response System)".

Radio communication with WLAN is done in so-called ISM (Industrial, Scientific \& Medical) frequency band. The activity of networks in this frequency band does not require issuing special permits (licenses) FTA (free to air) by authorized state bodies, provided that certain restrictions are respected, such as the strength of the broadcast signal.

ISM consists of three frequency ranges: 902$928 \mathrm{MHz}, 2400$ to $2483.5 \mathrm{MHz}$ and 5728 $5750 \mathrm{MHz}$ Nowadays, the most frequently used one is the range from $2.4 \mathrm{GHz}$ to $2.48 \mathrm{GHz}$.

In this research we have used technical resources of Electro Technical High School "Nikola Tesla" in Niš, Serbia (Table 1).

Table 1. Available resources of Electro Technical High School "Nikola Tesla" for the implementation of digital dialogue

\begin{tabular}{|c|c|}
\hline IS Components & $\begin{array}{c}\text { Electro Technical High } \\
\text { School "Nikola Tesla" } \\
\text { resources }\end{array}$ \\
\hline Web server & $\begin{array}{c}\text { HP ProLiant ML350e Gen8 } \\
\text { with Intel } ® \text { Xeon } ® \text { E5-2400 } \\
\text { CPUs }\end{array}$ \\
\hline $\begin{array}{c}\text { Operating } \\
\text { system }\end{array}$ & Windows Server 2012 R2 \\
\hline Internet & $\begin{array}{c}\text { Academic Network of Serbia } \\
\text { (AMRES) scientific, research } \\
\text { and educational network with } \\
\text { its external links (the } \\
\text { Internet, SEEREN, GEANT, } \\
\text { etc.), }\end{array}$ \\
\hline $\begin{array}{c}\text { Network } \\
\text { Personal mobile } \\
\text { device }\end{array}$ & $\begin{array}{c}\text { Wi-Fi routers TL-WR 340G } \\
{[14] \text { and AT-WA1104G [2] }} \\
\text { for IEEE 802.11b/g } \\
\text { standards }\end{array}$ \\
\hline $\begin{array}{c}\text { For every student: Android } \\
\text { OS 3.0 or higher }\end{array}$ \\
\hline
\end{tabular}


Compliance requirements for ICT components also include the integration of protective software components:

- Identity-Based Access Control - a system that controls network activities and eliminates excessive privileges, while, at the same time, enables each user to have a specific role, based on their identity. All of the students and teachers or any other users in digital dialogue must identify themselves by using their username, password and the unique device address. Based on that, they get the sufficient access to the resources of the system.

- Stateful Firewall - forming the appropriate firewall, which does not allow unauthorized access to network resources, and automatically turning off the unwanted devices from the system and simultaneously "blacklisting" them.

- Wireless Intrusion Detection - the solution for automatic reduction of threats, detection of intrusions in wireless transmission system by unauthorized users and "devices that roam the network".

\section{Safety requirements for the digital dialogue}

For the practical implementation of digital dialogue in teaching, apart from didactic and technical requirements, it is necessary to meet safety requirements in accordance with certain health care standards. Very frequently asked questions are those about safety and harmful effects of using wireless technologies, because devices used for transceiving of signal, so-called routers, emit high frequency electromagnetic rays and thus form an electromagnetic field around them. At the same time, in classes, students use mobile phones and smartphones which are also the source of electromagnetic radiation. In order to make sure that the concept of the digital dialogue can be implemented safely in the classroom, it is necessary to precisely determine the level of high-frequency radiation in the classroom during classes.
Devices for wireless telecommunication work on the principle of emitting high-frequency electromagnetic radiation (around $2.4 \mathrm{GHz}$ ). For this reason, there are logical questions related to the maximal values of strength of electromagnetic fields emanating from router antenna for wireless communication, and especially about the maximum controlled and uncontrolled exposure to this type of radiation.

These values are nowadays mostly covered and limited by appropriate standards $[5,10,22]$.

\section{Experimental analysis}

Measurements have been carried out in the laboratories Lab.112 and Lab.113 of the Electro Technical High School "Nikola Tesla" in Niš (Serbia), indoors, under normal laboratory conditions (pressure, temperature and humidity). The measurements of electric field strength, magnetic field strength and exposure to electromagnetic radiation were carried out by using the measuring instrument SPECTRAN HF 60105 [3] (Figure 2), specially designed to measure high-frequency electromagnetic radiation and its components. This instrument enables measuring RF signal, finding the sources of radiation, calculating the frequency and strength of the signal including the direct display of exposure limits.

The performances of DSP (Digital Signal Processor) allow calculations to determine exposure limits. The application software LCS Spectrum Analyzer (HF) has also been used together with the instrument.

First, wireless routers TL-WR $340 \mathrm{G}$ and ATWA1104G have been tested. The first router has been placed in the laboratory Lab.113, and the second one in the laboratory Lab.112.

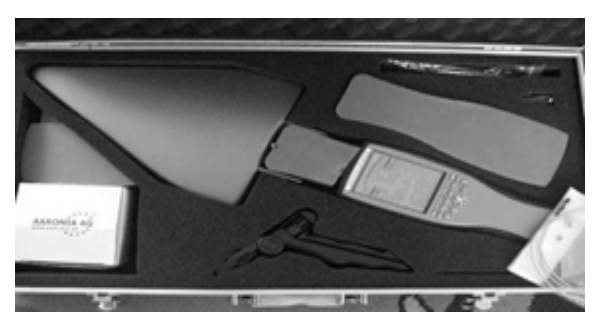

Figure 2. Set of the instruments SPECTRAN HF 60105 
During the measurement, both routers have been placed in the middle of laboratories at a height of $1.35 \mathrm{~m}$ from the floor, indoors, in the rooms of the same size (Figure 3).

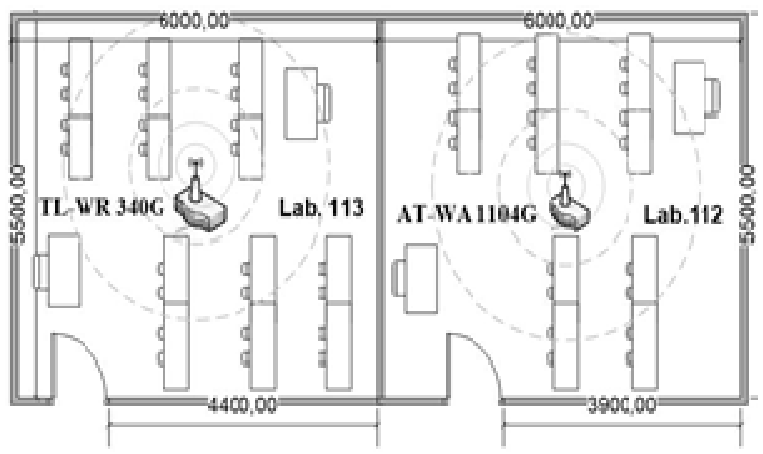

Figure 3. The positions of routers in relation to the size of space in Laboratory Lab.112 and Laboratory

Lab.113 during the measurement

For the purposes of measurement, the routers have been deliberately placed in the middle of both laboratories.

In the second phase, we have carried out the measurement of the strength of the electric and magnetic fields emitted by students' smartphones during the class, in 25 measuring points of the multimedia cabinet M8 (Figure 4). The cabinet M8 has the Internet connection, an LCD projector, a white board and a Wi-Fi router - teaching aids necessary for the digital dialogue.

The router is placed in the corner of the classroom, next to the projection canvas, at the height of $1.35 \mathrm{~m}$ from the floor. The measuring points have been positioned regularly in accordance with the dimensions of the classroom, with the distance of $140 \mathrm{~cm}$ in length and $116 \mathrm{~cm}$ in width of the classroom respectively.

\section{Results and discussion}

The measurements have been carried out by placing the measurement instrument from the middle of the router antenna to the distance of $30 \mathrm{~cm}$ from the middle of the antenna, in increments of $5 \mathrm{~cm}$. The dimensions of the router TL-WR $340 \mathrm{G}$ are $16 \mathrm{~cm} \times 10.2 \mathrm{~cm} \mathrm{x}$ $2.8 \mathrm{~cm}$, while the dimensions of the router ATWA1104G are $15.55 \mathrm{~cm} \times 10.55 \mathrm{~cm} \times 2.6 \mathrm{~cm}$.

Besides the stated values, we have measured the maximum distance from which we can
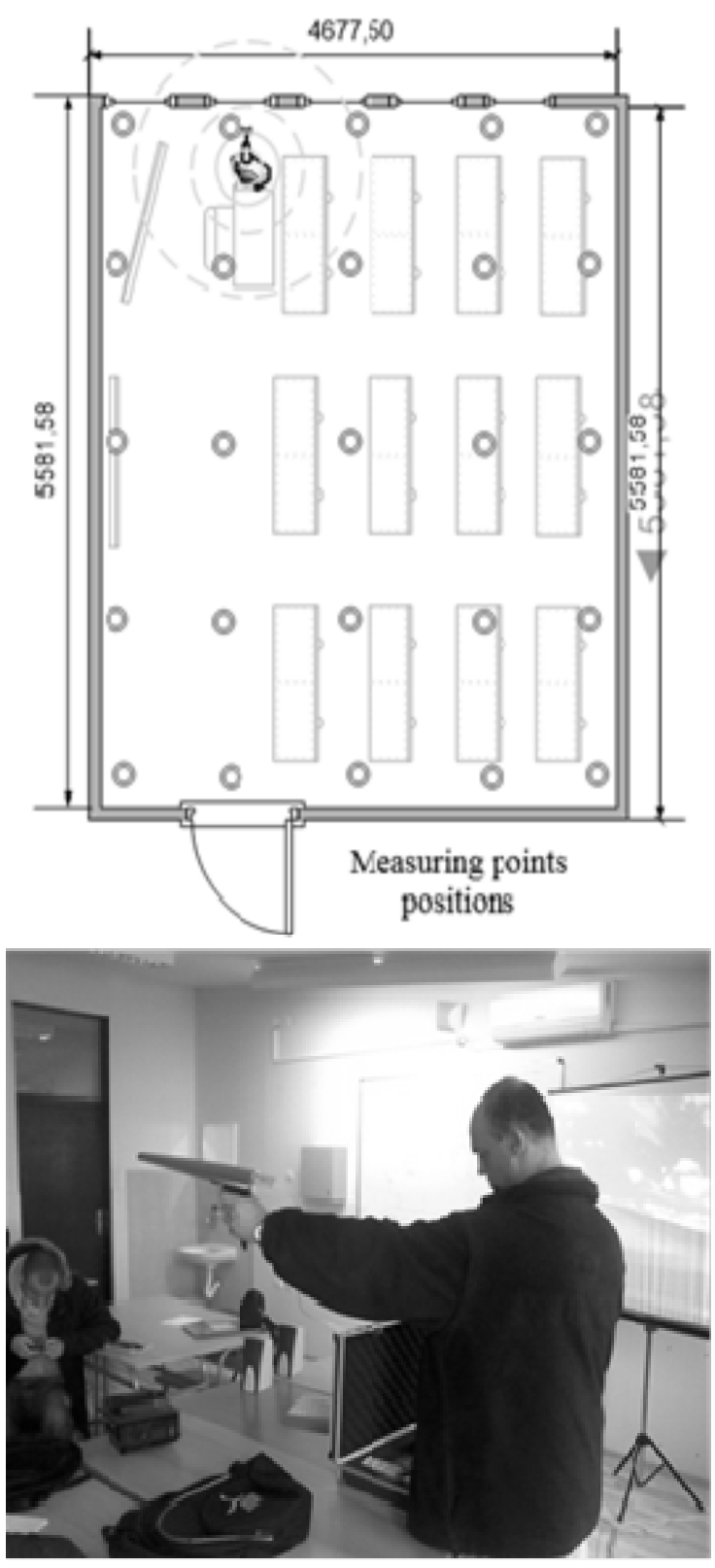

Figure 4. The positions of measuring points in the cabinet M8 and the measurement procedure with the instrument SPECTRAN HF 60105

receive the signal from the router, which has shown significantly lower results than those specified in the technical manual for the router.

Thus, for example, for the router ATWA1104G it is stated that the maximal distance of propagation of the signal in so-called "indoors conditions" is $120 \mathrm{~m}$. The obtained results have shown significantly lower values on the same floor the maximum distance was 63.5 and for the floors above and below the 
floor where the laboratory Lab.112 is located, the maximum distances have been $45.6 \mathrm{~m}$ and $42.76 \mathrm{~m}$. For the router TL-WR $340 \mathrm{G}$ the obtained results have been even lower.

Working frequencies of the devices measured by the instrument have mostly shown the value of $2.452 \mathrm{GHz}$ for TL-WR $340 \mathrm{G}$ router and $2.413 \mathrm{GHz}$ for AT-WA1104G router, which is in accordance with the official specifications of the devices.

It should be noted that the measurements of the strengths of the electric and magnetic fields of aforementioned routers have been repeated several times and that they have been carried out during the classes in the laboratories. Based on the obtained results the values of the power flow density $\left(\mathrm{mW} / \mathrm{cm}^{2}\right)$ have also been calculated, with and without the influence of additional radiation (Figure 7). During these measurements the students' smartphones have been switched off.

The obtained results of the measurements have been shown by line charts representing the strengths of the electric (Figure 5) and magnetic fields (Figure 6) of the routers depending on the distance between a measuring point and the router antenna. Maximum strengths of the electric fields of AT-WA $1104 \mathrm{G}$ and TL-WR $340 \mathrm{G}$ routers were 0.018 and $0.016 \mathrm{~V} / \mathrm{m}$ respectively, while maximum strength of the magnetic fields were 0.0020 and $0.0015 \mathrm{~A} / \mathrm{m}$ respectively.

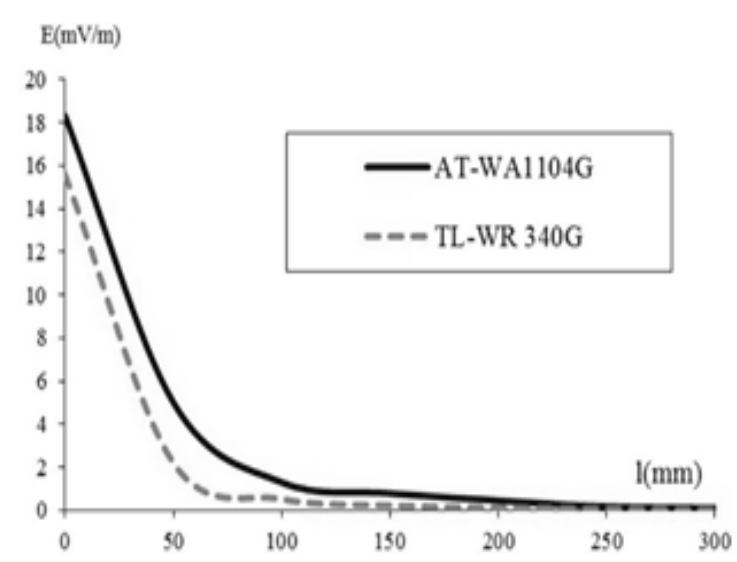

Figure 5. The strength of the electric fields of ATWA $1104 \mathrm{G}$ and TL-WR $340 \mathrm{G}$ routers

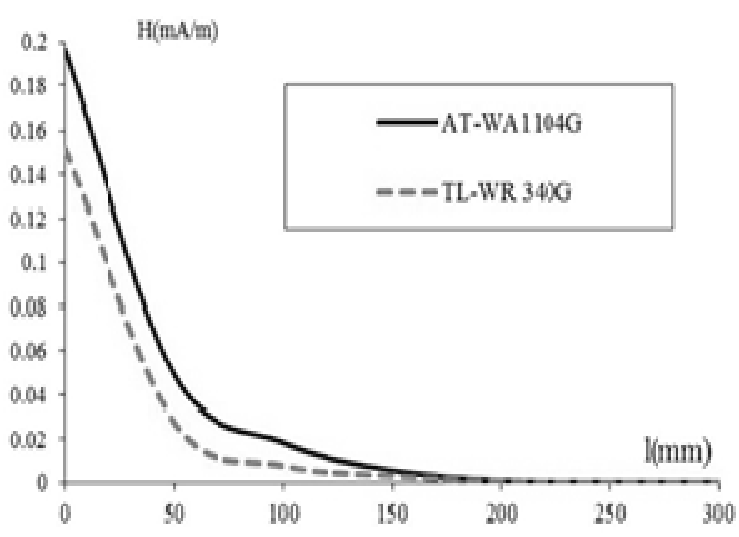

Figure 6. The strength of the magnetic fields of ATWA $1104 \mathrm{G}$ and TL-WR $340 \mathrm{G}$ routers

If we compare the obtained values for the strengths of electric (Figure 5) and magnetic fields (Figure 6) to the relevant international (ICNIRP, 1998 [10]) and Serbian reference levels (Official Gazette of the Republic of Serbia, no. 104/2009 [22]), we can see that the obtained values are much lower than the values permitted by standards (Table 2). Therefore, we can claim that the wireless routers are safe to be used in classrooms, especially if we bear in mind that strengths of their electromagnetic fields drop significantly at the distance of only $50 \mathrm{~cm}$ from the device.

Table 2. Allowed values of strength of electric and magnetic fields for population and occupational exposure

\begin{tabular}{|l|l|l|l|l|}
\hline & & $\begin{array}{l}\text { Frequency } \\
\boldsymbol{f}(\mathbf{G H z})\end{array}$ & $\begin{array}{l}\text { Electric } \\
\text { field } \\
\mathbf{E}(\mathbf{V} / \mathbf{m})\end{array}$ & $\begin{array}{l}\text { Magnetic } \\
\text { field } \\
\mathbf{H}(\mathbf{A} / \mathbf{m})\end{array}$ \\
\hline $\begin{array}{l}\text { ICNIRP } \\
{[10]}\end{array}$ & $\begin{array}{l}\text { Occupatio- } \\
\text { nal }\end{array}$ & $2-300$ & 61 & 0.16 \\
\hline $\begin{array}{l}\text { Serbian } \\
\text { regulati- } \\
\text { ons [22] }\end{array}$ & & $2-10$ & 24.4 & 0.064 \\
\hline
\end{tabular}

It has also been important, from the aspect of safety, to determine the intensity of electromagnetic radiation, as the amount of energy transmitted per area unit. Since routers have non-directional emission antennas, the same amount of energy is spread in all directions.

The results of the conducted measurements of the exposure to electromagnetic radiation, and 
the same values obtained by calculation are presented in Figure 7.

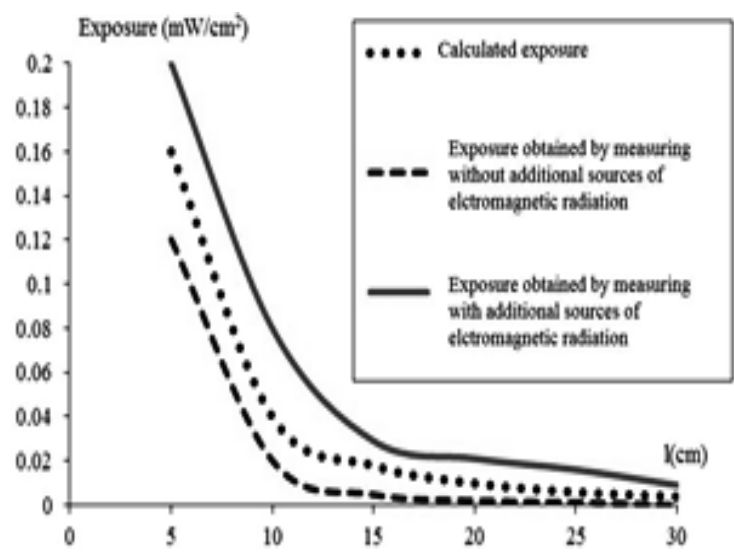

Figure 7. Comparative chart of the results of exposure on various distances from the AT-WA $1104 \mathrm{G}$ router antenna

The results have shown that even the measured values at $5 \mathrm{~cm}$ distance are much lower than maximum values permitted by C95.1-2005 standard [5] (Table 3). This also supports the above claim about the use of wireless routers in classrooms.

Students' smartphones radiation measurement results have shown that increasing the number of devices that radiate results in the increase of electric and magnetic field strength, proportionally to their proximity. The measurements have been carried out in 25 evenly distributed points, with the distance of $116 \mathrm{~cm}$ from each other in width and $140 \mathrm{~cm}$ in length of the classroom respectively. During the measurement there have been 26 smartphones in use at the same time in the classroom. The students have used different models of mobile telephones, made by different manufacturers, which also means creating different electromagnetic fields of different densities.

Table 3 Allowed values of electromagnetic radiation according to IEEE C95.1 [5]

\begin{tabular}{|c|c|c|}
\hline $\begin{array}{l}\text { Frequency } \\
\text { range }\end{array}$ & $\begin{array}{l}\text { Controlled } \\
\text { exposure } \\
\left(\mathrm{mW} / \mathrm{cm}^{2}\right) \\
(6 \mathrm{~min})\end{array}$ & $\begin{array}{l}\text { Uncontrolled } \\
\text { exposure } \\
\left(\mathrm{mW} / \mathrm{cm}^{2}\right) \\
(30 \mathrm{~min})\end{array}$ \\
\hline $\begin{array}{l}1.5-100 \\
\mathrm{GHz}\end{array}$ & 5 & 1.0 \\
\hline
\end{tabular}

The measurement results obtained in the classroom during the digital dialogue have been shown as 3D charts of electric field strength (Figure 8) and magnetic field strength (Figure 9) in the classroom.

The charts represent the measured values depending on the positions of the measuring points in the classroom. For the sake of the more realistic graphic interpretation, the strength of the electric field is presented by the measurement unit $[\mathrm{V} / \mathrm{m}]$ and the strength of the magnetic field by the measurement unit $[\mathrm{mA} / \mathrm{m}]$. From the graph we can see that the highest measured strengths of the electric field (Figure 8) and of the magnetic field (Figure 9) have been recorded in the measuring points in the middle of the classroom $0.167 \mathrm{mV} / \mathrm{m}$ and $0.652 \mathrm{~mA} / \mathrm{m}$ respectively. By comparing the measured values with the permitted values of strength of the electric and magnetic fields for general population and occupational exposure (Table 2), we can observe that the radiation level even in the most exposed measuring points is far below the maximum permitted values.

Hence, it can be concluded that smartphones are safe to be used in classrooms in the manner specified in the paper.

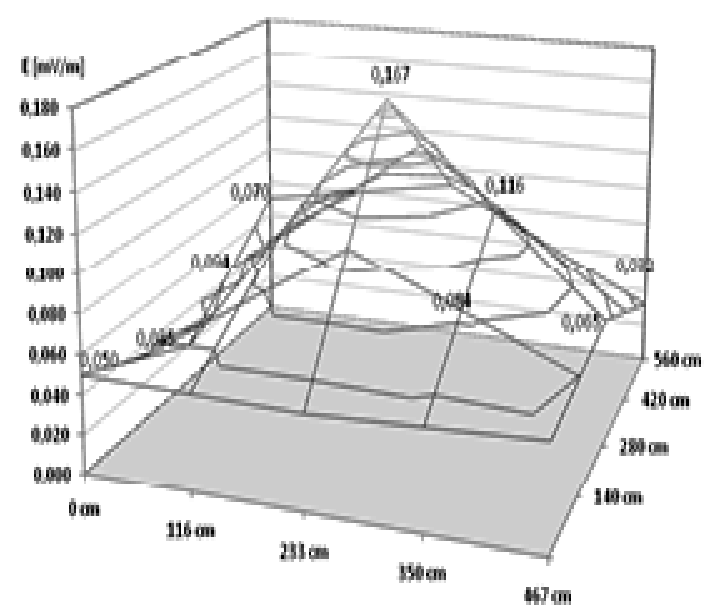

Figure 8. 3D chart showing the measurement results of the strength of the electric field of students' smartphones during the digital dialogue in the classroom 


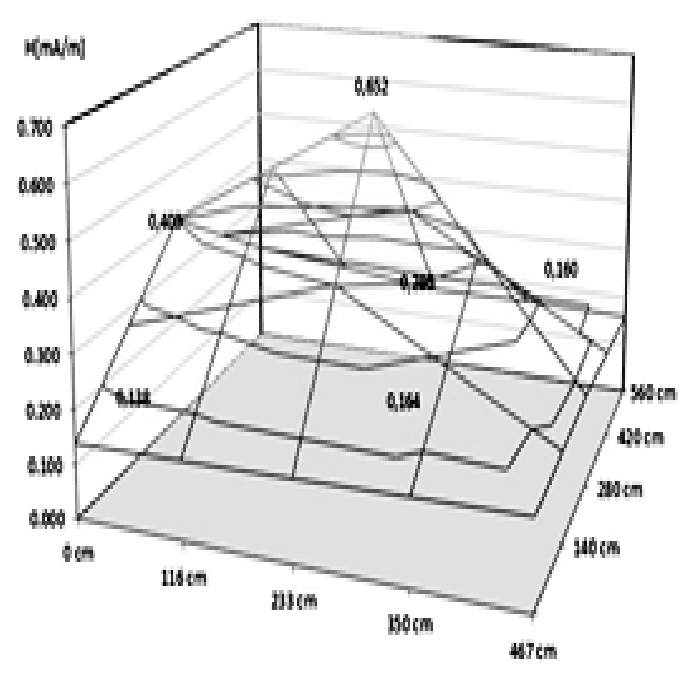

Figure 9. 3D chart showing the measurement results of the strength of the magnetic field of students' smartphones during the digital dialogue in the classroom

It is assumed that the charts showing the measured values of the strength of the electric and magnetic fields of the smartphones would have been more evenly distributed if all the students had used the same smartphones and if the analysis had excluded the radiation effects of the routers and external emitters.

According to the obtained results for the measurements of both wireless routers and students' mobile telephones, we can assert that the digital dialogue in education is safe and has no bad sides from the point of view of health impact.

\section{Conclusion}

Based on the results of this research it can be concluded that the implementation of digital dialogue in blended learning is safe in terms of the exposure of students to electromagnetic radiation, since the measured values are much lower than maximum permitted limits, prescribed by standards.

During the use of routers and mobile smart internet devices at school (where the density of users is very high), even in the situations when there are other sources of electromagnetic radiation, radiation did not exceed the permitted limits. The strength of electric and magnetic fields of smartphones had the highest value in the middle of the classroom. This suggests that future research will be focused on the high-frequency radiation in smaller classrooms with greater number of various devices that use wireless technology, bigger classrooms with greater number of students and bowl-shaped classrooms such as university amphitheatres and auditoriums.

\section{REFERENCES}

1. Agarwal, A., Deepinder, F., Sharma, R., Ranga, G. \& Li, J. (2008). Effect of cell phone usage on semen analysis in men attending infertility clinic: an observational study, Fertility and Sterility, 89(1), pp. 124-128.

2. Alied Telesis, Wireless Router ATWA1104G Manual issue, Available at: http://www.alliedtelesis.com/p-2411.html

3. Aronia A. G., Spectran manual, Available at: http://www.aaronia.com/products/ spectrum-analyzers/HF-60100-V4-EMCSpectrum-Analyzer

4. Bester, G. \& Brand, L. (2013). The effect of technology on learner attention and achievement in the classroom, South African Journal of Education, 33(2), pp. 1-15.

5. C95.1-2005 - IEEE Standard for Safety Levels with Respect to Human Exposure to Radio Frequency Electromagnetic Fields, $3 \mathrm{kHz}$ to $300 \mathrm{GHz}$, ASNSI/IEEE Standard C95.1, NewYork

6. Dawoud, M. (2003). High Frequency Radiation and Human Exposure. In Proceedings of International Conference on Non-Ionizing Radiation at UNITEN (ICNIR 2003) Electromagnetic Fields and Our Health Universiti Tenaga Nasional, Kuala Lumpar, pp. 1-7. 
7. Deepinder, F., Makker, K. \& Agarwal, A. (2007). Cell phones and male infertility: dissecting the relationship, Reproductive BioMedicine Online, 15(3), pp. 266-270.

8. Economides, A. \& Grousopoulou, A. (2010). Mobiles in education: Students' usage, preferences and desires, International Journal of Mobile Learning and Organisation, 4(3), pp. 235-252.

9. Haintz, C., Pichler, K. \& Ebner, M. (2014). Developing a Web-Based Question-Driven Audience Response System Supporting BYOD, Journal of Universal Computer Science, 20(1), pp. 39-56.

10. ICNIRP Guidelines for limiting exposure to time-varying electric, magnetic and electromagnetic fields (up to 300 GHz), (1998). Health Physics, 74(4), pp. 494-522.

11. Khurana, V. (2009). Health risks of cell phone technology, Surgical Neurology, 72(4), pp. 436-437.

12. Khurana, V., Teo, C., Kundi, M., Hardell, L. \& Carlberg, M. (2009). Cell phones and brain tumors: a review including the longterm epidemiologic data, Surgical Neurology, 72(3), pp. 205-214.

13. Krstić, D., Marković, V., Đinđić, B., Radić, S., Petković, D. \& Marković, M. (2004). The biological effects of radiation wireless communication systems, Acta Medica Medianae, 43(4), pp. 55-63.

14. Limitless Wireless, Wireless Router TLWR 340G User Guide, Available at: http://www.tp-

link.com/resources/document/TLWR340G_V3_User_Guide.pdf

15. Lukman, R. \& Krajnc, M. (2012). Exploring Non-traditional Learning Methods in Virtual and Real-world Environments, Educational Technology \& Society, 15(1), pp. 237-247.
16. Makker, K., Varghese, A., Desai, N., Mouradi, R. \& Agarwai, A. (2009). Cell phones: modern man's nemesis? Reproductive BioMedicine Online, 18(1), pp. 148-157.

17. Patrick, K., Griswold, W., Raab, F. \& Intille, S. (2008). Health and the Mobile Phone, American Journal of Preventive Medicine, 35(2), pp. 177-181.

18. Ranđelović, M., Veljović, A., Stanojević, Lj. \& Paunović, L. (2016). The effects of digital dialogue in teaching programming, In Proceedings of the $6^{\text {th }}$ International Conference Technics and Informatics in Education, Faculty of Technical Sciences, Čačak, Serbia, pp. 160-165.

19. Ravenscroft, A. \& McAlister, S. (2006). Designing interaction as a dialogue game: linking social and conceptual dimensions of the learning process, Chapter 4 in "Interactions in Online Education", Juwah, C (Ed). Routledge, pp. 73-88.

20. Ravenscroft, A. (2001). Dialogue and Connectivism: A New Approach to Understanding and Promoting DialogueRich Networked Learning, International Review of Research in Open and Distance Learning, 12(3), pp. 139-160.

21. Ravenscroft, A. (2007). Promoting thinking and conceptual change with digital dialog games, Journal of Computer Assisted Learning, available at: http://www.interloc.org.uk/publications_fil es/DDGs_JCAL(AR).pdf

22. Regulation on Non-Ionizing Radiation Exposure Limits, Official Gazette of the Republic of Serbia, no. 104/2009

23. Repacholi, M. (2001). Health risks from the use of mobile phones, Toxicology Letters, 120(1-3), pp. 323-331. 
24. Sarıtaş, M. (2015). The Enmergent Technological and Theoretical Paradigms in Education: The Interrelations of Cloud Computnig (CC), Conectivism and Internet of Things (ToI), Acta Polytechnica Hungarica, 12(6), pp. 161-179.

25. Saville, B., Lawrence, N. \& Jakobsen, K. (2012). Creating Learning Communities in the Classroom, New Directions for Teaching and Learning, 132, pp. 57-69.
26. Thorsteinsson, G. \& Niculescu, A. (2012). Using Mobile Technology for Problem Need Identification in School-aged Children Environment, Studies in Informatics and Control, 21(4), pp. 431-438.

27. Thorsteinsson, G., Gunnarsdottir, R., \& Niculescu, A. (2015). Assessing the Value of a Mobile Application in Fostering Ideation within a School Context, Studies in Informatics and Control, 24(1), pp. 119-126. 